\title{
Defense Reaction of Barley Cultivars to Non-Pathogenic Fungi
}

\author{
Norio SAHAShi* and Jiko Shishiyama*
}

\begin{abstract}
Defense reaction of barley cultivars to three nonpathogenic fungi were studied microscopically to clarify whether there are differences among cultivars and the nature of nonhost resistance was discussed by comparing with that of race-specific resistance. In all barley cultivars and non-pathogenic fungi combinations, it is shown that the penetration failure by non-pathogenic fungi was almost associated with papilla formation and cell wall alteration which fluoresced under fluorescence microscopy, of leaf epidermal cells. It is therefore suggested that papilla formation and cell wall alteration associated with defense reaction is major components of nonhost resistance in barley. In addition these components of nonhost resistance are most likely related to the induced resistance caused by previous inoculation with hypo-and hyper-virulent pathogens.
\end{abstract}

(Received December 10, 1986)

Key words : nonhost resistance, barley, pathogen non-pathogenic to barley, papilla formation, autofluorescence.

\section{Introduction}

Nonhost resistance was defined by Heath ${ }^{1)}$ as the resistance shown by plant species not considered to be hosts for the pathogen. Attention has been focused on it because it is not only highly effective to the majority of microorganisms but also greatly durabile $^{2)}$. For example, Sherwood and his co-worker ${ }^{9,12,13)}$ using reed canarygrass and fungi non-pathogenic to it, indicated that papilla or appositional cell wall thickness and its lignification might play important roles in resistance to fungal penetration. Later, they hypothesized that all species of Gramineae characteristically respond to fungal penetration attempts by appositional wall formation ${ }^{10)}$. Ride and Pearce ${ }^{7)}$ showed that failure of Botrytis cinerea to penetrate the intact surface of primary wheat leaves was closely associated with the production of lignified papilla and alteration of upper epidermal and adjacent lateral walls, and discussed their possible roles in resistance.

On nonhost resistance in barley, however, a few observations are reported and most of them have been studied using only one cultivar ${ }^{10,14)}$. As pointed out by Heath ${ }^{2)}$ and Sherwood and Vance ${ }^{10)}$, it is important and interesting to clarify whether or not there are differences in responses among lines and cultivars within a host species.

The purpose of this experiment is to clarify microscopically whether or not defence reaction of barley to some nonpathogenic fungi differs among cultivars and to discuss

\footnotetext{
* Laboratory of Plant Pathology, Faculty of Agriculture, Kyoto University, Kyoto 606, Japan
} 京都大学農学部 
the nature of nonhost resistance.

\section{Materials and Methods}

Plants and fungi. Five barley cultivars (Hordeum vulgare L.), Goseshikoku (GS), Kobinkatagi (KB), Hanna (HA), Russian No. 12 (R12) and Turkey 290 (TK) were used in the present study. These plants were grown in vermiculite supplied with $0.02 \%$ Hyponex solution every other day in a growth chamber maintained at $20 \pm 1 \mathrm{C}$ with $12 \mathrm{~h}$ photoperiod.

Alternaria alternata (Fries) Keissler, Erysiphe polygoni DC. and Colletotrichum lagenarium (Pass.) Ellis et Halsted were used as non-pathogenic inocula to barley. A. alternata was isolated from a sunflower plant by Dr. Tsuda, Pesticide Research Institute, Faculty of Agriculture, Kyoto University and maintained on potato sucrose agar (PSA) medium. E. polygoni (KU 86-1) was isolated from common buckwheat in the experimental field of Kyoto University and maintained on its host. C. lagenarium (104-T, Stock culture in Laboratory of Plant Pathology, Kyoto University) was maintained on PSA medium.

Preparation of inocula and inoculation. Conidia of A. alternata grown on PSA medium at $25 \mathrm{C}$ for 7 to 8 days were collected with a soft hair brush, washed three times with distilled water by centrifugation, and then conidia were suspended in $0.05 \%$ Tween 20 solution to give a final concentration of $5 \times 10^{3}$ conidia $/ \mathrm{ml}$. Fresh conidia of E. polygoni formed on buckwheat leaves 15 days after inoculation were used as inocula. Conidia of $C$. lagenarium were obtained by the same methods as those for $A$. alternata and adjusted to a final concentration of $3 \times 10^{3}$ conidia $/ \mathrm{ml}$.

Ten leaves of 7-day-old barley were fixed with rubber bands horizontally on a plastic sheet $(19 \times 18 \mathrm{~cm})$ and $30 \mathrm{ml}$ of conidial suspension of either A. alternata or $C$. lagenarium was sprayed onto the adaxial surface of the leaves. Inoculated plants were placed in a clear plastic case with water to give a high relative humidity throughout the experiment and incubated in a growth chamber described above. Inoculation with conidia of E. polygoni was conducted by shaking diseased plants over $30 \mathrm{~cm}$ height and incubated as mentioned above.

Preparation of specimens and observation. Inoculated leaves were harvested at appropriate times. Fixation, staining and observation were conducted by the methods described by Tosa and Shishiyama ${ }^{11}$.

For A. alternata, 20 conidia (60 to 100 attempted penetration sites), and for E. polygoni and C. lagenarium. more than 500 conidia on three leaves were observed.

\section{Results}

Symptoms on barley cultivars to three non-pathogenic fungi were observed 5 and 7 days after inoculation. No visible symptom was observed on all cultivars.

Results of microscopic observation on A. alternata were summarized in Table 1. About $90 \%$ of conidia germinated $6 \mathrm{~h}$ after inoculation on all cultivars. By $48 \mathrm{~h}$ after in- 
oculation 61 to 98 appressoria were formed per 20 conidia which had formed 3.1 to 4.9 appressoria in average. More than $90 \%$ of attempted penetration from these appressoria failed with papilla which fluoresced under fluorescence microscopy. (Fig. 1 A, B). Only 1 penetration was observed in HA and R12 36h after inoculation.

About $90 \%$ of conidia of $E$. polygoni germinated 6 h after inoculation and more than

Table 1. Development of Alternaria alternata on leaf epidermal cells on barley

\begin{tabular}{|c|c|c|c|c|c|}
\hline \multirow[b]{2}{*}{ Cultivar } & \multirow{2}{*}{$\begin{array}{c}\text { Time after } \\
\text { inoculation } \\
\text { (h) }\end{array}$} & \multirow{2}{*}{$\begin{array}{c}\text { Germination } \\
\text { percentage } \\
(\%)\end{array}$} & \multicolumn{3}{|c|}{ Number of sites per 20 conidia showing } \\
\hline & & & $\begin{array}{l}\text { Appressorial } \\
\text { formation }\end{array}$ & $\begin{array}{l}\text { Penetration } \\
\text { failure with } \\
\text { papilla }\end{array}$ & $\begin{array}{l}\text { Successful } \\
\text { penetration }\end{array}$ \\
\hline \multirow{3}{*}{ Goseshikoku } & 24 & 94.3 & $12(0.6)^{a)}$ & $8(66.7)^{b)}$ & $\left.0(0.0)^{b}\right)$ \\
\hline & 36 & 93.4 & $55(2.8)$ & $51(92.7)$ & $0(0.0)$ \\
\hline & 48 & 93.3 & $70(3.5)$ & $66(94.6)$ & $0(0.0)$ \\
\hline \multirow{3}{*}{ Russian No. 12} & 24 & 94.3 & $18(0.9)$ & $18(100.0)$ & $0(0.0)$ \\
\hline & 36 & 94.3 & $45(2.3)$ & $39(86.7)$ & $1(2.2)$ \\
\hline & 48 & 93.4 & $98(4.9)$ & $97(98.9)$ & $0(0.0)$ \\
\hline \multirow{3}{*}{ Turkey 290} & 24 & 96.6 & $15(0.8)$ & $14(93.3)$ & $0(0.0)$ \\
\hline & 36 & 95.3 & $39(2.0)$ & $38(97.4)$ & $0(0.0)$ \\
\hline & 48 & 96.2 & $64(3.2)$ & $62(96.9)$ & $0(0.0)$ \\
\hline \multirow{3}{*}{ Hanna } & 24 & 96.1 & $48(2.4)$ & $43(89.6)$ & $0(0.0)$ \\
\hline & 36 & 97.1 & $55(2.8)$ & $53(96.4)$ & $1(1.8)$ \\
\hline & 48 & 88.9 & $61(3.1)$ & $60(98.4)$ & $0(0.0)$ \\
\hline
\end{tabular}

a) Average number of appressoria per conidium.

b) Percentage.

Table 2. Development of Erysiphe polygoni on leaf epidermal cells of barley

\begin{tabular}{|c|c|c|c|c|c|c|}
\hline \multirow{2}{*}{ Cultivar } & \multirow{2}{*}{$\begin{array}{c}\text { Time after } \\
\text { inoculation } \\
\text { (h) }\end{array}$} & \multirow{2}{*}{$\begin{array}{c}\text { Germination } \\
\text { percentage } \\
(\%)\end{array}$} & \multirow{2}{*}{$\begin{array}{c}\text { Appressorial } \\
\text { formation } \\
\text { (\%) }\end{array}$} & \multicolumn{3}{|c|}{$\begin{array}{l}\text { Percentage of attempted penetration } \\
\text { sites showing }\end{array}$} \\
\hline & & & & $\begin{array}{c}\text { Failure with } \\
\text { papilla }\end{array}$ & \begin{tabular}{|c|} 
Failure with \\
$H \mathrm{R}^{\mathrm{a}}$
\end{tabular} & $\begin{array}{l}\text { Successful } \\
\text { penetration }\end{array}$ \\
\hline \multirow{3}{*}{ Goseshikoku } & 24 & 95.8 & 98.6 & 78.7 & 4.7 & 0.0 \\
\hline & 36 & 97.1 & 98.6 & 92.8 & 1.9 & 0.0 \\
\hline & 48 & 95.8 & 98.4 & 95.8 & 1.3 & 0.0 \\
\hline \multirow{3}{*}{ Kobinkatagi } & 24 & 89.2 & 97.5 & 58.3 & 1.8 & 0.0 \\
\hline & 36 & 92.3 & 96.2 & 74.0 & 2.6 & 0.0 \\
\hline & 48 & 91.7 & 97.1 & 76.1 & 4.8 & 0.0 \\
\hline \multirow{3}{*}{ Turkey 290} & 24 & 97.0 & 96.9 & 46.9 & 21.4 & 0.0 \\
\hline & 36 & 94.4 & 99.8 & 72.5 & 17.8 & 0.0 \\
\hline & 48 & 93.4 & 99.4 & 75.6 & 17.2 & 0.0 \\
\hline \multirow{3}{*}{ Hanna } & 24 & 96.7 & 98.4 & 71.3 & 0.9 & 0.0 \\
\hline & 36 & 96.0 & 99.2 & 90.0 & 1.1 & 0.0 \\
\hline & 48 & 95.0 & 97.5 & 90.3 & 0.0 & 0.0 \\
\hline \multirow{3}{*}{ Russian No.12 } & 24 & 89.2 & 97.6 & 80.7 & 5.9 & 0.0 \\
\hline & 36 & -b) & - & - & - & - \\
\hline & 48 & 93.9 & 97.7 & 76.5 & 8.5 & 0.5 \\
\hline
\end{tabular}

a) Hypersensitive reaction of epidermal cell.

b) Not observed. 
95\% of germinated conidia formed appressoria by $24 \mathrm{~h}$ on all cultivars. Even $48 \mathrm{~h}$ after inoculation, successful penetration was low or absent. However, unlike A. alternata, percentage of penetration failure with fluorescent papilla (Fig. $1 \mathrm{C}, \mathrm{D}$ ) ranged from 75 to $95 \%$ and it seemed to differ among the cultivars used. In TK, about $20 \%$ of attempted penetrations failed to develope haustorial initial with aggregation or granulation of cytoplasm (hypersensitive reaction) of epidermal cells (Table 2).

Results with C. lagenarium were shown in Table 3 . About $85 \%$ of conidia germinated $90 \%$ of them formed pigmented appressoria. However penetration failure with papilla which also fluoresced was low and its percentage was 13.4 to 45.5 and 19.9 to $46.4 \%$, 48 and $72 \mathrm{~h}$ after inoculation, respectively. By 5 days after inoculation more than $55 \%$ of conidia with normal appressoria failed to penetrate with papilla (Fig. 1 E, F). When appressoria were wiped off with a wet cotton ball to observe the site beneath them, however, a large number of papillae were observed beneath the appressoria even $48 \mathrm{~h}$

Table 3. Development of Colletotrichum lagenarium on leaf epidermal cells of barley

\begin{tabular}{|c|c|c|c|c|}
\hline \multirow{2}{*}{ Cultivar } & \multirow{2}{*}{$\begin{array}{l}\text { Time after } \\
\text { inoculation } \\
\text { (h) }\end{array}$} & \multirow{2}{*}{$\begin{array}{l}\text { Number of conidia } \\
\text { with normal } \\
\text { appressoria }\end{array}$} & \multicolumn{2}{|c|}{$\begin{array}{l}\text { Number of attempted penetration } \\
\text { sites showing }\end{array}$} \\
\hline & & & $\begin{array}{l}\text { Failure with } \\
\text { papilla }\end{array}$ & $\begin{array}{l}\text { Successful } \\
\text { penetration }\end{array}$ \\
\hline \multirow{3}{*}{ Goseshikoku } & 48 & 621 & $83(13.4)^{a)}$ & $0(0.0)^{a)}$ \\
\hline & 72 & 658 & $131(19.9)$ & $0(0.0)$ \\
\hline & 120 & 682 & $380(55.7)$ & $0(0.0)$ \\
\hline \multirow{3}{*}{ Kobinkatagi } & 48 & 606 & $81(13.4)$ & $0(0.0)$ \\
\hline & 72 & 634 & $141(22.2)$ & $0(0.0)$ \\
\hline & 120 & 850 & $485(57.1)$ & $0(0.0)$ \\
\hline \multirow{3}{*}{ Turkey 290} & 48 & 598 & $154(25.8)$ & $0(0.0)$ \\
\hline & 72 & 594 & $169(28.5)$ & $0(0.0)$ \\
\hline & 120 & 734 & $403(54.9)$ & $0(0.0)$ \\
\hline \multirow{3}{*}{ Hanna } & 48 & 809 & $368(45.5)$ & $0(0.0)$ \\
\hline & 72 & 939 & $436(46.4)$ & $0(0.0)$ \\
\hline & 120 & 610 & $413(67.7)$ & $0(0.0)$ \\
\hline \multirow{3}{*}{ Russian No. 12} & 48 & 529 & $146(27.6)$ & $0(0.0)$ \\
\hline & 72 & 552 & $177(32.1)$ & $0(0.0)$ \\
\hline & 120 & 552 & $376(68.1)$ & $0(0.0)$ \\
\hline
\end{tabular}

a) Percentage.

Table 4. Papilla formation in barley epidermal cells in response to attempted penetration by Colletotrichum lagenarium

\begin{tabular}{c|c|c|c|c}
\hline \hline Cultivar & $\begin{array}{l}\text { Time after ino- } \\
\text { culation (h) }\end{array}$ & $\begin{array}{l}\text { Number of } \\
\text { appressoria }\end{array}$ & $\begin{array}{l}\text { Number of } \\
\text { papilla }\end{array}$ & $\begin{array}{c}\text { Percentage } \\
\text { of papilla }\end{array}$ \\
\hline Goseshikoku & 48 & 1,484 & $1,104^{\mathrm{a}}$ & 74.4 \\
& 72 & 1,402 & 1,014 & 72.3 \\
Kobinkatagi & 48 & 1,621 & 1,094 & 67.5 \\
\hline
\end{tabular}

a) Papilla was observed after removing appressoria with wet cotton ball. 
after inoculation. The estimated number showed almost the same value in both 48 and $72 \mathrm{~h}$ after inoculation (Table 4, Fig. 2).

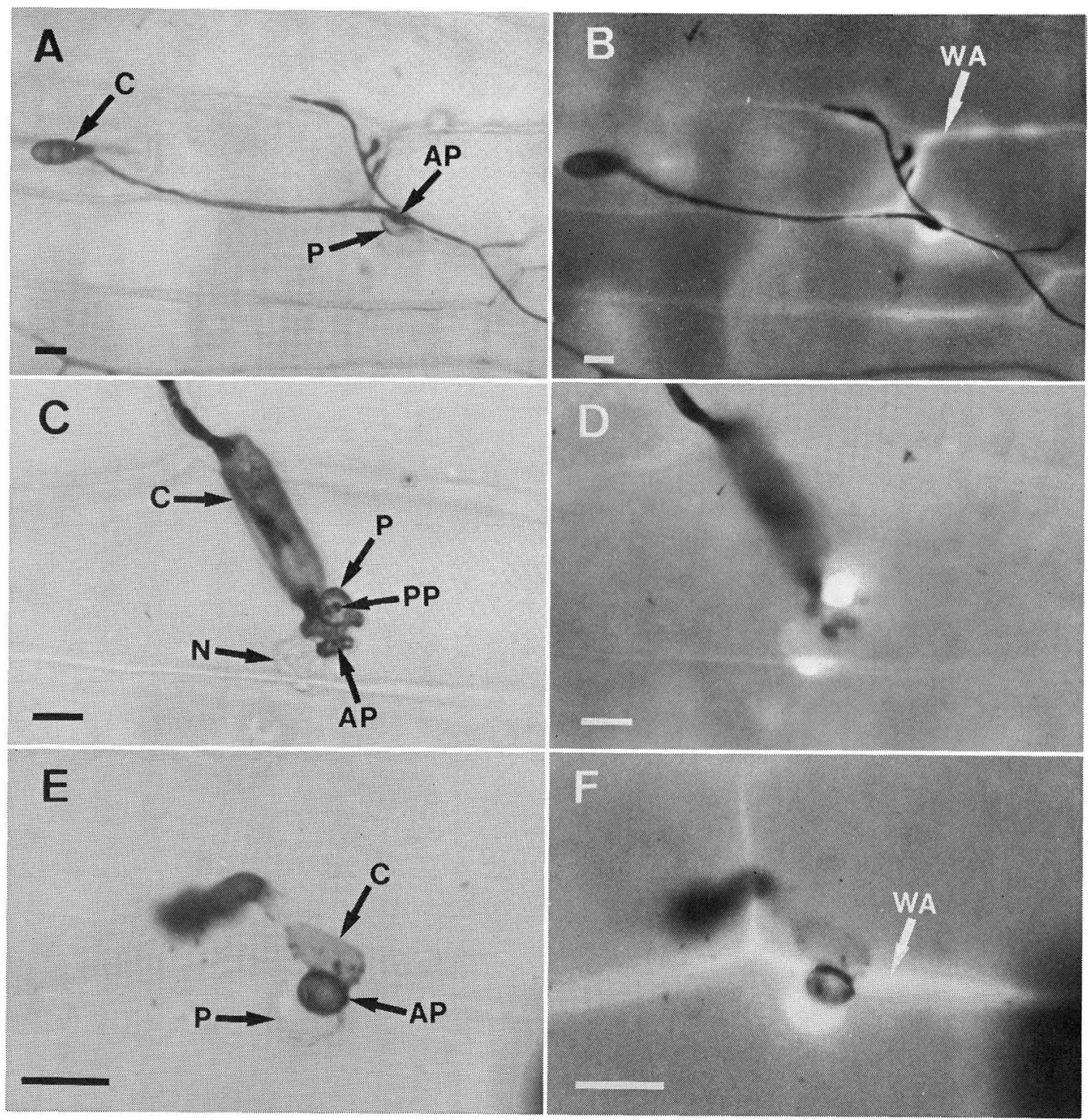

Fig. 1. Light (A, C and E) and fluorescence (B, D and F) microscopic photographs showing papilla formation in response to attempted penetration of three nonpathogenic fungi. A ; Papilla formed at attempted penetration site of $A$. alternata. B ; Same as A. Note that lateral wall adjacent to penetration site fluoresced, showing alteration of its site. C; Papilla formed at attempted penetration site of $E$. polygoni. Penetration peg was observed at the centre of papilla. D; Same as C. E; Papilla formed at attempted penetration site of $C$. lagenarium. F; Same as E. Lateral wall also fluoresced as those observed with $A$. alternata. AP ; Appressorium, C; Conidium, N; Nucleus, P; Papilla, PP; Penetration peg, WA; Wall alteration. Each bar represents $10 \mu \mathrm{m}$. 


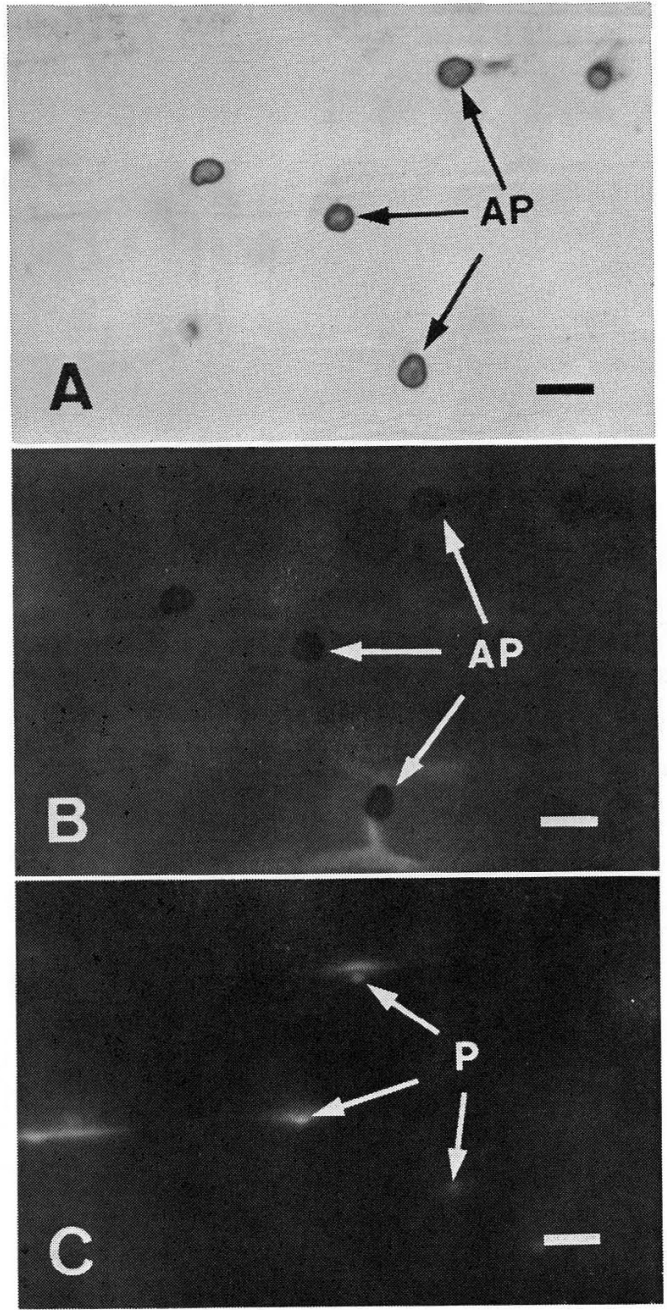

Fgi. 2. Papilla formation in barley epidermal cells in response to attempted penetration by $C$. lagenarium. A ; light microscopic photograph of inoculated barley epidermis. No reaction was observed. B ; Fluorescent microscopic photograph of the same site. C ; Fluorescent microscopic photograph showing papillae detected after removal of appressoria. Note that a large number of papillae were formed. $\mathrm{AP}$ and $\mathrm{P}$; Refer to Fig. 1. Each bar represents $10 \mu \mathrm{m}$.

\section{Discussion}

As defense reactions of plants against non-pathogenic fungi, lignified papilla ${ }^{7,9,12,13)}$, callosity $^{14)}$, appositional wall formation ${ }^{10}$ and lignification ${ }^{3,4,6)}$ at the penetration site have been reported in several plant species and their possible roles in defense reaction has been discussed. However, these results were obtained, in many cases, with only one plant cultivar.

In the present study it was shown using 5 barley cultivars that penetration failure by non-pathogens was almost associated with papilla formation and cell wall alteration, which fluoresced under fluorescence microscopy, although there are some differences among cultivars and fungi used. Therefore, papilla formation and cell wall alteration at the attempted penetration site may be major components of nonhost resistance at least in barley. However, it is unclear why the percentages of papilla formation were less than the others in TK and KB at $24 \mathrm{~h}$ after inoculation when $E$. polygoni was used. 
In E. polygoni, 10 to $25 \%$ of attempted penetration failed to develope haustorial initial with hypersensitive reaction of epidermal cell. This reaction may serve as a barrier after papilla formation because at these sites the fungus penetrated through a small papilla.

It has been suggested in race-specific interaction of barley cultivars and E. graminis f. sp. hordei that $J M l s n^{t}$ and $J M l r_{12}$, major genes for resistance, identified in TK and R12, respectively, control hypersensitive reactions of epidermal and mesophyll cells and that JMlh, identified in HA, controls mesophyll reaction at least ${ }^{11}$. No major gene, however, has so far been identified in GS and KB.

The results in the present study indicated that defense of barley to non-pathogenic fungi is due to the inhibition of penetration by papilla formation and that it might be distinguished from race-specific resistance which is mainly due to hypersensitive reactions of epidermal and mesophyll cells which fluoresced under fluorescence microscopy ${ }^{5,11}$. However, it is unclear whether or not there is substantial or essential difference between race-specific and nonhost resistance because there are some cases in which papilla formation plays important role to inhibit fungal penetration in incompatible combination of barley and E. graminis f. sp. hordei and the hypersensitive reaction of epidermal cell are also observed in nonhost barley plants. Therefore, comparative studies on recognition mechanisms in molecular level and on initiation time of defense reactions should be made in relation to specificity of race-cultivar and species-species levels.

In double inoculation system using barley and its powdery mildew fungi, Sahashi and Shishiyama ${ }^{8)}$ suggested that the increase of papilla formation is a major factor of induced resistance and discussed that the resistance induced might differ from racespecific resistance mediated by a single major gene. These findings together with the present study provide an important clue to understanding the nature of resistance induced by previous inoculation with hyper- and hypo-virulent pathogen.

Further studies should be conducted to clarify what the nature of nonhost and racespecific resistance is in many plant species.

We thank Dr. U. Hiura, Professor Emeritus, and Mr. H. Heta, Research Associate, Institute of Agricultural Biology, Okayama University, for their generous supply of barley cultivars. Thanks are also due to Dr. M. Tsuda, Associate Professor, Pesticide Research Institute, Kyoto University for his supply of the isolate of $A$. alternata.

\section{Literature cited}

1. Heath, M. C. (1981). Phytopathology $71: 1121-1123$.

2. Heath, M. C. (1981). Plant Disease Control. John Wiley \& Sons, New York. pp. 201-212.

3. Hammerschmidt, R. (1984). Physiol. Plant Pathol. 24 : 33-42.

4. Hammerschmidt, R., Bonnen, A. M., Bergstrom, G. C. and Baker, K. K. (1985). Can. J. Bot. 63: 2393-2398.

5. Kita, N., Toyoda, H. and Shishiyama, J. (1981). Ibid. 59 : 1761-1768.

6. Ride, J. P. (1975). Physiol. Plant Pathol. 5 : 125-134.

7. Ride, J. P. and Pearce, R. B. (1979). Ibid. $15: 79-92$.

8. Sahashi, N. and Shishiyama, J. (1986). Can. J. Bot. $64: 2178-2181$.

9. Sherwood, R. T. and Vance, C. P. (1976). Phytopathology $66: 503-510$. 
10. Sherwood, R. T. and Vance, C. P. (1980). Phytopathology $70: 273-279$.

11. Tosa, Y. and Shishiyama, J. (1984). Can. J. Bot. $62: 795-798$.

12. Vance, C. P. and Sherwood, R. T. (1976). Phytopathology 66:498-502.

13. Vance, C. P. and Sherwood, R. T. (1977). Physiol. Plant Pathol. $10: 247-256$.

14. Young, P. A. (1926). Bot. Gaz. $81: 258-279$.

\section{和 文 摘 要}

佐橋憲生・獅山慈孝：非病原性系状菌に対するオオムギ品種の防御反応

オオムギ 5 品種の第一葉に 3 種の非病原性系状菌, Alternaria alternata, Erysiphe polygoni および Colletotrichum lagenarium を接種し，それらオオムギ品種の防御反応を光学および蛍光顕微鏡を用いて観 察した。その結果, 供試した品種および系状菌間では, パピラによる侵入阻止率に差が認められた。しかし, ほとんどの侵入阻止部位では, パピラ形成や蛍光顕微鏡下で自発蛍光として現われる細胞壁の変化が観察され た。以上の結果から，パピラ形成によって起こる侵入阻止反応は，オオムギが非病原性糸状菌に対して示す抵 抗反応の一つとして重要であることが示唆された。 